\title{
A WISH questionnaire to measure the faculty perceptions of the medical simulation environment as their workplace
}

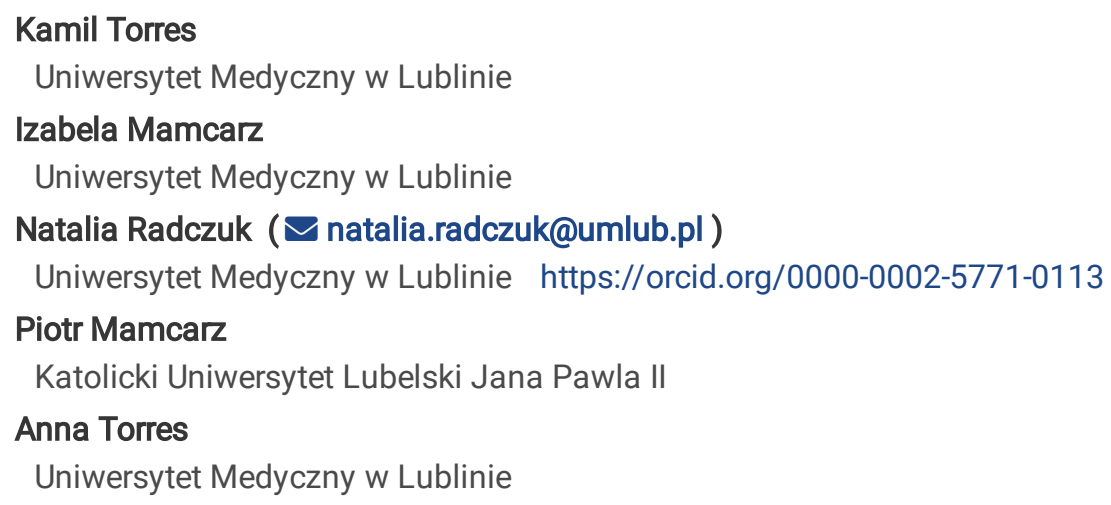

Research article

Keywords: medical education, simulation environment, academic teachers, workplace satisfaction, faculty development

Posted Date: June 29th, 2020

DOI: https://doi.org/10.21203/rs.3.rs-35411/v1

License: () (1) This work is licensed under a Creative Commons Attribution 4.0 International License. Read Full License 


\section{Abstract \\ Background}

The medical simulation environment is a specific type of work environment. It would seem essential for educators to have a tool with which they could identify its features to maximize the effectiveness of medical simulation - teachers' workplace - and optimize their work efforts. The purpose of this research study was to construct a proprietary tool, which would help to characterize the medical simulation environment as a type of work environment and also to identify particular factors that are important in organizing the educational environment in simulation.

\section{Methods}

At first, six faculty members took part in semi-structured interviews, whose findings were used to develop a standardized questionnaire consisting of 30 items. The authors then validated the questionnaire in a survey among the other 32 academic teachers involved in teaching with the use of medical simulation.

\section{Results}

The Work In Simulation Healthcare questionnaire addresses the aspects of teaching in a simulation environment referring to technicaladministrative conditions, teacher development, and the overall score. The Cronbach's alpha reliability index for the overall result of the questionnaire is $a=8.22$ based on standardized items; the reliability index for the scale of 'the technical and administrative conditions' and 'the professional development of teachers' is $a=0,57$ and $a=0,76$, respectively. The questionnaire allowed the authors to know the ratings of academic teachers for the two scales.

\section{Conclusions}

The Work In Simulation Healthcare questionnaire allows educators to identify the traits of the simulation-teaching environment. It provides the potential to optimize the conditions of medical simulation, improve the quality of teaching and the overall educational process, as well as design effective faculty development programs. The authors of this study consider the WISH questionnaire the first method of this type.

\section{Background}

Educators have been interested in studying the educational environment more thoroughly since the 1960s. With the first inventories, they started to evaluate the quality of the learning environment as its influence on the students' professional development has become more widely acknowledged. There are a few very useful tools, which have been used to investigate specific or general aspects of the educational environment; like the Dundee Ready Education Environment Measure [1], the John Hopkins Learning Environment Scale [2], or the Medical School Learning Environment Scale [3]. However, these tools do not gauge the specific aspects of the simulation environment, let alone include teachers as their subject.

A few authors conducted research related to medical simulation [4-9]. Some of them used the Satisfaction with Simulation Experience Scale to learn students' perspectives on the simulation learning experience or their satisfaction with a particular type of simulation equipment and methodology [10]. Nevertheless, hardly any study has been found describing the simulation environment as a specific kind of educational environment as seen by the academics as their work environment.

Contemporary medical simulation has become so significant and widely recognized teaching methodology that not only does it affect the medical education environment but also a successful implementation of the program curriculum. Its organization and effectiveness are highly dependent on the teachers, which, on the other hand, is further reflected in the students' perception of the education process and their performance. Acknowledging the importance of the simulation environment for the implementation of a wide range of clinical objectives, the authors attempted to characterize this particular type of education environment as the teachers' workplace. 
Teachers play an important role in shaping the conditions of the education environment, including the environment of medical environment. Their role is to make the most use of it so as to maximize the effectiveness of simulation methods and provide the students with the highest quality education. Their duty is to make this particular education environment resemble the conditions found in real clinical departments, but also to follow the requirements of good simulation teaching, that is: providing feedback, assuring coherence of the curriculum, meeting the standards of medical schools, diversifying the level of difficulty, using different teaching strategies, or controlling the environment. Due to their commitment, they individualize the learning process for students and let them study clearly defined clinical objectives giving them the opportunity to make, capture, and correct mistakes without negative consequences [11]. Although it creates more challenges for the teacher in terms of handling the equipment or using specific methodologies, it gives more opportunities for providing education when compared to classical forms of teaching, such as lectures or seminars. More frequent and deeper clinical interactions of students in a simulation setting allow them to integrate the cognitive and motoric content with knowledge and skills as well as enhance their professional development, which is paramount to the teachers' mission [12].

When planning the implementation of clinical objectives in the simulation environment it is necessary to take care about proper training of the teaching staff to work with the use of simulation methods. Their continuous education and improvement of qualifications are important for meeting the criteria of high-quality education for students in medical faculties [13]. Even though the simulation teachers' role gradually seems to be acknowledged, the authors of the study found no method with which it would be possible to identify the features of that specific educational environment as viewed by the teachers themselves.

In this paper, the authors wanted to present the construction and initial application of a new method used to gauge the teachers' perspectives on the simulation environment as their work environment. The information that can be obtained with this unique method may be useful to understand the simulation environment as an educational environment, to form the basis for the improvement and adjustment of educational conditions to implement the curriculum, and design faculty development programs.

\section{Methods}

\section{Construction of the Work In Simulation Healthcare (WISH) questionnaire}

Despite quite a few methods and questionnaires describing the educational environment or the attitude towards medical simulation, no method specifically designed for academic teachers' use has been found. Thus, it was considered necessary to construct an appropriate psychometric tool.

Teachers co-create the educational environment $[14,15]$. They are among the pillars of this environment. However, their work conditions are also organized by those, who manage education, including educators, administration staff, school authorities, and respective state departments of education. Thus, the great potential of simulation methods should be thoughtfully maintained to be used effectively. The authors of the study were determined to identify the aspects of that setting that need to be recognized and taken care of while organizing teachers' work in simulation. It was considered more valuable if the information would come directly from the people engaged with this particular environment. Hence the authors of the study invited the academics involved in simulation-based teaching and implementation of the curriculum with dedicated equipment and teaching methodologies.

A literature search helped to find available tools used to evaluate the education environment; included were: Dundee Ready Education Environment Measure [1], the John Hopkins Learning Environment Scale [2], and the Medical School Learning Environment Scale [3]. The authors of the study analyzed them to identify the aspects they found important for their research project; they were: curriculum implementation, interactions with the academic community, sense of the education climate, and facilities.

The construction of the tool (ethical approval no. KE-0254/241/201 of the Medical University of Lublin, Poland) started with semistructured interviews of six academic teachers who conducted classes in a simulation environment. The interview questions were created based on the information coming from the student research, observation of academic teachers' work, and literature on the subject. It consisted of a metric and 53 open questions addressing the aspects related to work in a simulation environment. The interviewees answered the questions using the CAWI (Computer Assisted Web Interview) method. Their analysis allowed the authors to create two main scales that were included in the design of the questionnaire-based tool: "the technical and administrative conditions" and "the professional development of teachers". The final version of the method, called the Work In Simulation Healthcare (WISH) questionnaire, included a metric and 30 items to which respondents were given a 5-point Likert scale: 'I completely agree (5)' and 'I 
completely disagree (1)' as the answer options. The questionnaire standards, along with its scales were divided into quartiles. Figure 1 presents the procedure of the WISH construction. [Figure 1 - near here]

Medical simulation is claimed to be an expensive teaching environment. However, if properly managed, these costs are cost-effective [16-19]. It is therefore considered important to include the financial aspect of available teaching resources in planning a simulationbased curriculum. For this reason it was also included in the WISH questionnaire. Studies by other authors also justify the distinction of such areas in the assessment of the educational environment by teachers [20]. The medical simulation environment as a specific type of educational environment also seems to fit into this trend. Moreover, research results indicate that there are specific factors and principles that teachers should be aware of when working with medical simulation [21]. This therefore justifies taking into account the scale of professional development of teachers, which should be an inherent factor of working in a simulation environment [22-24].

The reference for the above mentioned construction of the WISH questionnaire and validity of the distinction of the two scales related to the technical-administrative conditions and the professional development of teachers may be confirmed with the statement of Issenberg et al. (2006) [5], that the effective use of simulation assumes the presence of three components: training resources, trained educators, and curricular institutionalization. These aspects were also included in the WISH questionnaire. The literature refers to studies on the investigation of educational environment, however, it is the perspective of students rather than academic teachers [2, 26]. All the more important seems to be the construction of a new tool, allowing to define the teacher's perspective in terms of working in a simulation environment as a specific educational environment.

\section{The characteristic of the research process}

The first part of the survey was an online structured interview and the second part was a survey based on the interviews. The author who conducted the survey was PhD Izabela Mamcarz, an academic teacher, female. She had had the experience of collecting data for several studies as well as for two doctoral dissertations. She had also finished a seminary in methodology of social sciences.

Before the study commencement the relationship has been established between the participants. They learnt the goals of the survey and the fact that the survey was designed for cognitive, theoretical and practical goals. Another information the participants received were as follows: participation was voluntary; the survey consisted of a certificate and a questionnaire; the obtained research results would be analyzed and discussed from an empirical point of view, and would serve to answer the research questions posed in the study; the study was oriented on the assessment of teachers' work under simulation conditions; the completion of the questionnaire was an expression of consent to participate in the survey; the results of this survey would be processed anonymously and used only for scientific purposes. There was no facilitator in the research because the first part of the survey was a structured online form and the second one consisted of short sentences assessed by the participants with a Likert scale.

To underpin the study, the content analysis was stated. Participants were selected purposively; they were approached by online form and face-to-face. In the study there were 32 participants. No one refused to participate in the study nor dropped out.

The data was collected at home and no other person was present besides the participant and the researcher. The sample was academic teachers working in medical simulation environment. Questions were provided for the online form and then specific items were developed for the questionnaire step. No repeat interviews were carried out and no recording was used to collect the data. Because there weren't any facilitators, there were no field notes. The data saturation wasn't discussed.

One data coder coded the data. The themes for the first part of analysis were derived from the collected data. The participants didn't provide feedback on the findings. There was consistency between the data presented and the findings. The major themes were presented in the findings in the analysis of the two scales and the minor themes were described in the analysis of particular sentences of the questionnaire. The result of the first part of the survey was a survey on its own. It was planned as an initial stage in construction of a questionnaire for the second part of the survey and it should not be considered as a separate qualitative research.

\section{Characteristics of the study group}

The authors of the study used a targeted selection method to choose the participants for the project as a wish to get reliable information of the simulated environment. In their opinion this had to be academics with a professional experience in teaching with simulation methods. Thirty-two teachers of the Medical University of Lublin agreed to take part in the survey with the use of the new tool. The number was considered sufficient for this study project as it constituted about $10 \%$ of all academics involved in teaching with simulation methods at that university. 
The average age of the respondents was 39 years. The lowest value reported by the respondents was 25 , while the highest value was 56. Table 1 shows the average and standard deviation for the age of the participants based on the metric information. [Table 1. Age of respondents - near here]. Of the 25 academic teachers who provided the answers, 22 declared that they were clinically active. Figure 2 presents data on the teachers surveyed in terms of years of service. [Figure 2 - near here]. That information was further divided into two groups: short - up to seven-year long experience, and long, the experience of more than seven years in that field. This criterion was based on the fact that an average time of promotion at that university, from the position of an assistant to the position of an assistant professor, is seven years. Short-term job experience was reported by $34.4 \%$ of people, while long-service, by $65.6 \%$ of people.

Table 1

Age of respondents

\begin{tabular}{|llllll|}
\hline & N & M & SD & MIN & MAX \\
\hline Age & 32 & 39,06 & 8,68 & 25 & 56 \\
\hline
\end{tabular}

\section{Results}

The presented results describe the researched group of academics and come from data obtained with the authors' proprietary WISH questionnaire. Table 2 presents the average and standard deviation for the overall score of the respondents $(N=32)$ of the questionnaire and two scales "the technical and administrative conditions" and "the professional development of the teachers". The average result obtained from the general questionnaire was 124.86, with a minimum value of 107 and a maximum value of 144 . On the scale of "the technical-administrative conditions" the average value was $M=25$, for a minimum value of 21 and a maximum value of 30. In contrast, on the scale "professional development of the teachers", the respondents obtained the average value of answers given $M=99.63$, with a minimum value of 82 and a maximum value of 115. [Table 2. Mean and standard deviation for the WISH method - near here]

Table 2

The mean and standard deviation for the WISH method

\begin{tabular}{|llllll|}
\hline WISH & N & M & SD & MIN & MAX \\
\hline Technical-administrative conditions & 32 & 25 & 2,27 & 21 & 30 \\
\hline Development of teachers & 32 & 99.63 & 7,01 & 82 & 115 \\
\hline WISH General Score & 32 & 124.86 & 8,11 & 107 & 144 \\
\hline
\end{tabular}

Cronbach's alpha reliability index for the overall result of the WISH questionnaire is $\alpha=8.22$ based on standardized items. The reliability index of Cronbach's alpha for the scale of Technical and administrative conditions and Professional development of teachers is as follows: $a=0,57$ and $a=0,76$.

Women and men scored almost the same on the scale of "the technical-administrative conditions" $(W=25,09, M=25,60)$. Similar results were obtained on the scale "professional development of the teachers" ( $W=99.41, M=100.10)$ and the overall result of the WISH questionnaire $(W=124,50, M=125,70)$. Higher values on the scales "technical-administrative conditions" $(25,36$ vs. 23,67$)$, "professional development of teachers" $(101,00$ vs. 96,33$)$ and the overall WISH result $(126,36$ vs. 120,00$)$ were obtained by the clinically active employees.

The descriptive analysis in the scale of "the technical-administrative condition" revealed two items to which $100 \%$ of respondents selected "agree" or "completely agree." All of them "agreed" or "completely agreed" that the number of exercise groups is an essential factor influencing the effectiveness of the content (item 8) and additional equipment, or the interior design of the room increases the realism of the scenario (item 20). The knowledge about the capabilities of simulation equipment as being essential for the effective conduct of classes in simulated conditions (item 4) was an important factor for $93,76 \%$ of the respondents. More than $50 \%$ of the respondents were not sure if the cost of simulated classes is higher than in a clinic (item 25). More than $81 \%$ of them mostly agreed with the fact that the cost of work with simulated methods is an important aspect of learning planning (item 28). About $75 \%$ of the surveyed academics supported the fact that the technical problems often make it difficult to conduct classes in simulated conditions (item 3). 
Taking into consideration the second scale, "the professional development of the teachers" - there were six items to which $100 \%$ of the surveyed participants agreed or completely agreed, they were:

- - conducting classes in a simulated environment requires a proper organization of time (item 5);

- - an adequately prepared scenario helps to implement the content of courses in simulated conditions effectively (item 6);

- - standardized patients increase the realism of classes conducted in simulated conditions (item 9);

- - the effectiveness of simulated sessions depends on the level of preparation of the teacher and the student (item 18);

- - medical simulation is an essential complement to clinical teaching (item 26);

- - and medical simulation is a reliable method of teaching (item 27).

More than $90 \%$ of the respondents agreed or completely agreed with the following statements:

- - divisibility of attention is an important skill when conducting classes in a simulated environment (item 2);

- - ensuring safe conditions for students to practice their skills is an important feature of a simulated classroom environment (item 10);

- - each teacher conducting classes in simulated conditions shall receive training in operating simulation equipment (item 12);

- - the effectiveness of simulated sessions is enhanced by ensuring a high level of realism in the scenario (item 16);

- - simulated conditions allow the effective realization of learning outcomes (item 19);

- - debriefing is the most challenging stage of conducting classes in simulated conditions (item 22).

About $84 \%$ of the teachers agreed or completely agreed with the fact that debriefing is an essential stage of conducting classes in simulated conditions (item 21), and carrying out classes in a simulated environment can be a challenge for the teacher (item 24). There are a few statements where more than $70 \%$ of respondents marked 4 or 5 on a Likert scale. According to the results, $75,01 \%$ of respondents selected they agree or completely agree with the fact that they feel well prepared to teach in a simulated environment (item 1); 78,13\% - that, conducting classes in a simulated environment requires a more open attitude towards the student (item 7); $71,88 \%$ that, the simulation environment can be stressful for the student (item 23) and 71,55\% that, working with simulated methods requires a higher level of qualifications from the teacher, i.e., communication skills (item 15). Almost $70 \%$ of the respondents agreed or completely agreed with the fact that the teachers would like to improve their qualifications necessary to conduct classes in simulated conditions (item 13); the effectiveness of simulated methods is higher than in traditional classes (item 14); and that the teacher's communication skills in the simulated environment should be higher than in the conventional environment (item 17). More than $40 \%$ of the surveyed participants completely disagreed or disagreed with the fact that the difficulty in effective implementation of classes is more often on the student than the teacher (lack of preparation, involvement) (item 11). The results were quite equally distributed in the items 29 (Teachers were aware of the costs associated with the use of simulated methods in teaching) and 30 (Teachers consider the costs of teaching using simulated methods in the planning of lesson plans).

\section{Discussion}

The results presented in this article draw attention to the fact that for the surveyed academics the aspects related to their work environment, the technical-administrative conditions as well as professional development are important when managing the teaching process in a simulated environment. All teachers agreed that the external aspects, such as the number of simulation session groups, additional equipment and interior design of the room are important in organizing this process. Paying attention to the equipment, teachers were also aware of the fact that their knowledge about that specific equipment is essential. As referred to another aspect included in "the technical-administrative conditions" scale - the costs of simulating classes - the surveyed academics were not sure about the difference between expenses involved in teaching classes in simulation conditions or in a clinic. They were not aware of the high costs of the former, which may be an important factor in planning the education process.

Proper organization of time and planning functional scenarios for simulation sessions were important for all surveyed participants. They also found the involvement of the simulated patients intrinsic in the implementation of simulation sessions and agreed that the effectiveness of the sessions depends on the teacher's and the student's preparation. They considered simulation as an essential complement to clinical teaching and a reliable method of teaching. 
The surveyed participants agreed with the statement that work in simulation requires teachers' preparation for classes, a thoughtful organization of the teaching plan, implementation of special methodologies and well-established technical-administrative conditions of the simulation setting. Since it is a complex process it requires appropriate decisions based on experience, available literature, and reliable research results.

The shortage of health professionals, including doctors in Poland, triggered a series of system-based changes in the undergraduate education system. The changes included implementing a new Higher Education Act and introducing new standards of education, i.e., medical simulation. The Polish government invested in a network of Simulation Centres based in Polish medical schools and required the application of the simulation methods for providing education to students of medical curricula. Included were: a transfer of minimum of $5 \%$ of clinical education into simulation conditions, employment of simulated patients to assist students' professional skills acquisition in the patient-doctor communication and the implementation of the Objective Structured Clinical Examination (OSCE) aimed at the assessment of health care students' professional skills and competencies. The above mentioned system-based requirements raised the need to expand the pool of qualified faculty capable of carrying out simulation-enhanced educational process. To be able to establish an effective simulation environment, develop high standards for students learning with the use of medical simulation and hold the responsibility for teachers' qualifications in that field, the authors of this study aimed to create a standardized tool, which could help to characterize the medical simulation environment as teachers' workplace. In addition, the designed questionnaire enabled the assessment of the individual aspects that make up the simulation environment as an education environment.

Harden and Crosby (2000) [27] list twelve teacher roles that can be classified into six areas:

(1) Teacher as a provider of relevant information in the teaching process in lectures or a clinical context,

(2) Teacher as a role model performing his or her medical specialty,

(3) Teacher as a facilitator and mentor,

(4) Teacher as a student evaluator and curriculum,

(5) Teacher as a person planning and designing the curriculum and courses,

(6) Teacher as a source material organizer.

The authors point out that some teachers' roles are more focused on a person with medical knowledge, and some emphasize the role of an educator.

The effectiveness of the methods and methodology depends on the teacher's knowledge and involvement [12]. It is the teacher who has the opportunity to decide on the type of a teaching method, curriculum design, implementation of educational objectives, and the legitimacy of applied tools. The conditions of the simulation environment that must be provided for the teaching to bring the expected outcomes can only occur with the participation of academic teachers, the majority of whom are regular clinicians. Their expertise in the field of patient care is precious; however, their availability is often limited due to clinical obligations. With medical simulation requiring a unique teaching methodology, concentration, and attentive evaluation of students' skills and competencies, the educational load of medical simulation teachers is much higher. What is more, the knowledge of the academic teacher's role, the scope of his or her duties or expectations related to the implementation of the education process is critical in the process of matching the teachers' tasks to the existing curriculum, the faculty evaluation, as well as designing programs for faculty development.

The authors of the study embraced the information mentioned above to look for the answer to their research question - what is the teachers' perspective on their work in the medical simulation environment. The initial stage was based on the interviews, which revealed certain tendencies in the opinion of academics regarding working in simulated conditions. Then, further works aimed to design a more standardized tool - the Work in Simulation Healthcare questionnaire.

The construction of the WISH questionnaire proved to be effective for describing the perspectives of academic teachers on their work in simulated conditions. The questionnaire seems to fill up the niche in this particular research area, and to present the applicability of the new tool its construct was juxtaposed with the DREEM [1], JHLES [2], MSLES [3] and SSES [10] inventories. As demonstrated in Table 3, the new questionnaire addresses the same aspects of a general education environment as the above-mentioned well- 
established tools; however, the area of the study is narrowed, in that case, to simulation conditions. [Table 3. Comparison of the DREEM, JHLES, MSLES, SSES, WISH - near here]. Another unique feature of this tool is that the authors changed the source of information from the students to academic teachers. It also allows expanded evaluation of the educational environment by investigating both students' and teachers' preparedness to classes, as this mutually affects the perspectives of the learning and teaching processes. 
Table 3

Comparison of the DREEM, JHLES, MSLES, SSES, WISH

\begin{tabular}{|c|c|c|c|c|c|}
\hline & DREEM & JHLES & MSLES & SSES & WISH \\
\hline PURPOSE & $\begin{array}{l}\text { To measure the } \\
\text { educational } \\
\text { environment and } \\
\text { climate of health } \\
\text { professions/ } \\
\text { medical schools } \\
\text { professions to } \\
\text { permit evaluation } \\
\text { of their responses } \\
\text { to the challenges } \\
\text { of changing } \\
\text { mandates and } \\
\text { missions }\end{array}$ & $\begin{array}{l}\text { To measure students' } \\
\text { perceptions of the } \\
\text { learning environment } \\
\text { that would capture } \\
\text { the richness and } \\
\text { variety of each } \\
\text { student's relational, } \\
\text { academic and } \\
\text { institutional } \\
\text { engagement in } \\
\text { medical school }\end{array}$ & $\begin{array}{l}\text { To measure } \\
\text { students' } \\
\text { perceptions of } \\
\text { their learning } \\
\text { environment to } \\
\text { plan appropriate } \\
\text { interventions in } \\
\text { the educational } \\
\text { program and to } \\
\text { assess their } \\
\text { impact on } \\
\text { students' } \\
\text { academic } \\
\text { performance }\end{array}$ & $\begin{array}{l}\text { To measure and } \\
\text { compare } \\
\text { differences in } \\
\text { satisfaction } \\
\text { levels between } \\
\text { nursing students } \\
\text { exposed to } \\
\text { medium and high } \\
\text { fidelity human } \\
\text { patient } \\
\text { simulation } \\
\text { manikins }\end{array}$ & $\begin{array}{l}\text { To characterize } \\
\text { the medical } \\
\text { simulation } \\
\text { environment as a } \\
\text { type of working } \\
\text { environment }\end{array}$ \\
\hline Date of creation & 1996 & $2011-2012$ & 1976 & $2009-2010$ & 2019 \\
\hline $\begin{array}{l}\text { Number of } \\
\text { respondents }\end{array}$ & $\begin{array}{l}\text { First intervention } \\
\text { 1996: } 42 \text { Dundee } \\
\text { University medical } \\
\text { students; } \\
\text { In total between } \\
\text { 1996-1997: } 721 \\
\text { students of } \\
\text { medicine and } \\
\text { nursing program }\end{array}$ & $\begin{array}{l}377 \text { medical } \\
\text { students }\end{array}$ & $\begin{array}{l}93 \text { medical } \\
\text { students }\end{array}$ & $\begin{array}{l}344 \text { nursing } \\
\text { students }\end{array}$ & $\begin{array}{l}32 \text { teachers of the } \\
\text { medical program }\end{array}$ \\
\hline Number of items & 58 & 28 & 50 & 18 & 30 \\
\hline $\begin{array}{l}\text { Aspects of the } \\
\text { learning } \\
\text { environment }\end{array}$ & $\begin{array}{l}\text { GENERAL } \\
\text { LEARNING } \\
\text { ENVIRONMENT } \\
\text { AND CLIMATE }\end{array}$ & $\begin{array}{l}\text { GENERAL LEARNING } \\
\text { ENVIRONMENT AS A } \\
\text { WHOLE }\end{array}$ & $\begin{array}{l}\text { GENERAL } \\
\text { LEARNING } \\
\text { ENVIRONMENT }\end{array}$ & $\begin{array}{l}\text { SIMULATION } \\
\text { LEARNING } \\
\text { EXPERIENCE }\end{array}$ & $\begin{array}{l}\text { SIMULATION } \\
\text { LEARNING } \\
\text { ENVIRONMENT }\end{array}$ \\
\hline $\begin{array}{l}\text { Applicable to: type } \\
\text { of } \\
\text { school/profile/level } \\
\text { of education }\end{array}$ & $\begin{array}{l}\text { medical schools } \\
\text { and other health } \\
\text { training settings/ } \\
\text { undergraduate }\end{array}$ & $\begin{array}{l}\text { medical school/ } \\
\text { undergraduate }\end{array}$ & $\begin{array}{l}\text { medical school/ } \\
\text { undergraduate/ } \\
\text { basic science } \\
\text { years }\end{array}$ & $\begin{array}{l}\text { nursing school/ } \\
\text { undergraduate }\end{array}$ & $\begin{array}{l}\text { medical school/ } \\
\text { undergraduate }\end{array}$ \\
\hline Curriculum & $\begin{array}{l}\text { - S's perception of } \\
\text { the learning } \\
\text { process/curriculum }\end{array}$ & $\begin{array}{l}\text { - S's perception of } \\
\text { the curriculum }\end{array}$ & $\begin{array}{l}\text { - S's perception } \\
\text { of the } \\
\text { meaningful } \\
\text { learning } \\
\text { experience - } \\
\text { curriculum } \\
\text { - S's perception } \\
\text { of the degree to } \\
\text { which LE fosters } \\
\text { interest and } \\
\text { activity in } \\
\text { medicine - } \\
\text { Breadth of } \\
\text { interest } \\
\text { - S's perception } \\
\text { of the } \\
\text { organization of } \\
\text { the learning } \\
\text { process } \\
\text { - S's perception } \\
\text { of the flexibility - } \\
\text { the pattern of } \\
\text { school control } \\
\text { imposed on the } \\
\text { students }\end{array}$ & $\begin{array}{l}\text { - S's assessment } \\
\text { of the simulation } \\
\text { experience } \\
\text { - S's perception } \\
\text { of the extent to } \\
\text { whish SE helped } \\
\text { to integrate } \\
\text { knowledge with }\end{array}$ & $\begin{array}{l}\text { - T's perception of } \\
\text { the extent to } \\
\text { which SE allows } \\
\text { the successful } \\
\text { implementation } \\
\text { of the curriculum }\end{array}$ \\
\hline
\end{tabular}




\begin{tabular}{|c|c|c|c|c|c|}
\hline & DREEM & JHLES & MSLES & SSES & WISH \\
\hline \multirow[t]{2}{*}{$\begin{array}{l}\text { Interactions with } \\
\text { the academic } \\
\text { community }\end{array}$} & $\begin{array}{l}\text { - S's perception of } \\
\text { teachers/ teaching } \\
\text { skills and } \\
\text { interactions with } \\
\text { students }\end{array}$ & $\begin{array}{l}\text { - S's perception of } \\
\text { teachers }\end{array}$ & $\begin{array}{l}\text { - S's perception } \\
\text { of the interaction } \\
\text { with faculty and } \\
\text { staff }\end{array}$ & \multirow[t]{2}{*}{$\begin{array}{l}\text { - S's assessment } \\
\text { of the teacher's } \\
\text { support - hints, } \\
\text { discussion, } \\
\text { feedback }\end{array}$} & \multirow[t]{2}{*}{$\begin{array}{l}\cdot \text { T's perception of } \\
\text { the students and } \\
\text { their preparation } \\
\text { to classes }\end{array}$} \\
\hline & $\begin{array}{l}\text { - S's perception of } \\
\text { the social self }\end{array}$ & $\begin{array}{l}\text { - S's perception of } \\
\text { other students } \\
\text { - S's perception of } \\
\text { the administration }\end{array}$ & $\begin{array}{l}\text { - S's perception } \\
\text { of peer-relations }\end{array}$ & & \\
\hline $\begin{array}{l}\text { Sense of the } \\
\text { learning climate }\end{array}$ & $\begin{array}{l}\text { - S's perception of } \\
\text { the learning } \\
\text { atmosphere } \\
\text { - S's perception of } \\
\text { academic self }\end{array}$ & $\begin{array}{l}\text { - S's sense of the } \\
\text { learning climate/ fair } \\
\text { and understandable } \\
\text { - S's sense of } \\
\text { inclusion and safety } \\
\text { - S's sense of the } \\
\text { institutional ethos }\end{array}$ & $\begin{array}{l}\text { - S's perception } \\
\text { of the emotional } \\
\text { climate, sense of } \\
\text { stress } \\
\text { - S's perception } \\
\text { of the extent to } \\
\text { which the school } \\
\text { supports them by } \\
\text { caring or } \\
\text { providing } \\
\text { assistance }\end{array}$ & $\begin{array}{l}\text { - S's perception } \\
\text { of the extent to } \\
\text { which simulation } \\
\text { experience } \\
\text { helped them to } \\
\text { recognize their } \\
\text { clinical strengths } \\
\text { and weaknesses } \\
\text { - S's assessment } \\
\text { of their } \\
\text { development and } \\
\text { self-reflection }\end{array}$ & $\begin{array}{l}\text { - T's perception of } \\
\text { the extent to } \\
\text { which SE/SM } \\
\text { affects both } \\
\text { teachers and } \\
\text { students' } \\
\text { emotions towards } \\
\text { teaching/learning, } \\
\text { e.g., sense of } \\
\text { stress }\end{array}$ \\
\hline Facilities & $\mathrm{n} / \mathrm{a}$ & $\begin{array}{l}\text { - S's perception of } \\
\text { the } \\
\text { facilities/workspaces }\end{array}$ & $\mathrm{n} / \mathrm{a}$ & $\begin{array}{l}\text { S's perception of } \\
\text { the simulation } \\
\text { experience about } \\
\text { the medium- and } \\
\text { high-fidelity } \\
\text { human patient } \\
\text { simulation } \\
\text { manikins }\end{array}$ & $\begin{array}{l}\text { - T's assessment } \\
\text { of simulation } \\
\text { conditions } \\
\text { (realism)/ } \\
\text { technical } \\
\text { problems } \\
\text { - T's perception of } \\
\text { the costs of SE }\end{array}$ \\
\hline Other & $\mathrm{n} / \mathrm{a}$ & $\mathrm{n} / \mathrm{a}$ & $\mathrm{n} / \mathrm{a}$ & $\begin{array}{l}\text { S's perception of } \\
\text { debriefing skills } \\
\text { of the faculty }\end{array}$ & $\begin{array}{l}\cdot \text { T's assessment } \\
\text { of their } \\
\text { methodological } \\
\text { qualifications to } \\
\text { teach with MS } \\
\text { and the ability to } \\
\text { operate the } \\
\text { simulation } \\
\text { equipment }\end{array}$ \\
\hline Limitations & $\begin{array}{l}\text { - Does not examine } \\
\text { the simulation } \\
\text { environment as a } \\
\text { learning/teaching } \\
\text { environment }\end{array}$ & $\begin{array}{l}\text { - Conducted at a } \\
\text { single institution } \\
\text { - Does not explore } \\
\text { the simulation } \\
\text { environment as a } \\
\text { learning/teaching } \\
\text { environment }\end{array}$ & $\begin{array}{l}\text { - Does not } \\
\text { explore the } \\
\text { simulation } \\
\text { environment as a } \\
\text { learning/teaching } \\
\text { environment }\end{array}$ & $\begin{array}{l}\text { - Is limited to } \\
\text { examine } \\
\text { simulation } \\
\text { experience not a } \\
\text { comprehensive } \\
\text { aspect of the } \\
\text { simulation } \\
\text { environment as a } \\
\text { learning/teaching } \\
\text { environment }\end{array}$ & $\begin{array}{l}\text { - Created and } \\
\text { validated at a } \\
\text { single institution } \\
\text { - A small number } \\
\text { of participants }\end{array}$ \\
\hline
\end{tabular}

The authors of the presented study project have found no other tools in the available literature that would specifically identify the factors helping to describe golden standards for setting up effective simulation environment and allow the academics to provide their viewpoint on these issues. The WISH questionnaire was designed to identify these factors and to understand the perspectives of academic teachers on working in a simulation environment. The presented research results highlight the areas which most of the surveyed participants found relevant when working in a simulation environment. The authors of that research project consider the results of their survey useful and potentially applicable worldwide when deciding on the process of organizing and teaching simulation-based curriculum.

\section{Limitations}


A high-reliability index of the entire method in the initial version of the tool makes the measurement reliable. To improve the reliability of individual scales, coefficients items with low discriminatory power (less than 0.3) should be removed and re-analyzed. To determine all the psychometric values of the method, a large population of academic teachers should also be examined.

\section{Conclusions}

Medical simulation is a unique educational environment for students. It has great potential, which, to be fully utilized, requires skillful management by the teachers [27]. To be able to establish an effective simulation environment, develop high standards for students' education with the use of medical simulation and hold the responsibility for teachers' qualifications in that field, the authors of this research project wanted to characterize the medical simulation environment as teachers' workplace, thus created a standardized tool called the Work In Simulation Healthcare questionnaire. The authors consider the WISH questionnaire the first method of this type.

\section{Abbreviations}

CAWI - the Computer Assisted Web Interview

WISH - the Work In Simulation Healthcare questionnaire

OSCE - the Objective Structured Clinical Examination

DREEM - the Dundee Ready Education Environment Measure

JHLES - the John Hopkins Learning Environment Scale

MSLES - the Medical School Learning Environment Scale

SSES - the Satisfaction with Simulation Experience Scale

\section{Declarations}

\section{Authors' Contribution}

KT has made substantial contributions to the conception and designing the work; IM has carried out both stages of the study, the interviews and questionnaire stage, and analyzed the data; NR has made literature search, language revision, and preparation of the manuscript; PM has contributed to the analysis of the data; AT substantively revised the work

\section{Competing Interest}

The authors report no declarations of interest.

\section{Consent for Publication}

Not applicable

\section{Funding}

The authors received no financial support for the research, authorship, and/or publication of this article.

\section{Ethics Approval and Consent to Participate}

This study was approved by the Medical University in Lublin - Ethical approval no. KE-0254/241/2019 and performed following the ethical standards as laid down in the 1964 Declaration of Helsinki and its later amendments. The participants were informed, that filling in the questionnaires equals their consent to participate in the survey.

\section{Acknowledgments}

The authors would like to thank the participants for their involvement in this research project. 
Data access will be considered upon request from Ms. Natalia Radczuk: natalia.radczuk@umlub.pl

\section{References}

1. Roff S. The Dundee Ready Educational Environment Measure (DREEM) - A generic instrument for measuring students' perceptions of undergraduate health professions curricula. Med Teach. 2005.

2. Shochet RB, Colbert-Getz JM, Wright SM. The johns hopkins learning environment scale: Measuring medical students' perceptions of the processes supporting professional formation. Acad Med. 2015.

3. Marshall RE. Measuring the medical school learning environment. J Med Educ. 1978.

4. Treadwell I, Grobler S. Students' perceptions on skills training in simulation. Med Teach. 2001.

5. Issenberg SB. The scope of simulation-based healthcare education. Simulation in healthcare: journal of the Society for Simulation in Healthcare. 2006.

6. Morgan PJ, Cleave-Hogg D, Desousa S, Lam-Mcculloch J. Applying theory to practice in undergraduate education using high fidelity simulation. Med Teach. 2006.

7. Scalese RJ, Obeso VT, Issenberg SB. Simulation technology for skills training and competency assessment in medical education. Journal of General Internal Medicine. 2008.

8. McGaghie W, Siddall V, Mazmanian P, Myers J. Lessons for continuing medical education from simulation research in undergraduate and graduate medical education: effectiveness of continuing medical education: American College of Chest Physicians Evidence-Based Educational Guidelines. Chest. 2009.

9. Torres K, Kański A (editors. Symulacja w edukacji medycznej. Lublin; 2018. http://podrecznik.mediq.edu.pl.

10. Levett-Jones T, McCoy M, Lapkin S, Noble D, Hoffman K, Dempsey J, et al. The development and psychometric testing of the Satisfaction with Simulation Experience Scale. Nurse Educ Today. 2011;31:705-10. doi:10.1016/j.nedt.2011.01.004.

11. Issenberg SB, McGaghie WC, Petrusa ER, Gordon DL, Scalese RJ. Features and uses of high-fidelity medical simulations that lead to effective learning: A BEME systematic review. Medical Teacher. 2005.

12. Weinberger S. The medical educator in the 21st century: a personal perspective. Trans Am Clin Climatol Assoc. 2009.

13. Ramani S. Twelve tips to promote excellence in medical teaching. Med Teach. 2006.

14. Enns SC, Perotta B, Paro HB, Gannam S, Peleias M, Mayer FB, et al. Medical Students' Perception of Their Educational Environment and Quality of Life: Is There a Positive Association? Acad Med. 2016.

15. Moutier C, Wingard D, Gudea M, Jeste D, Goodman S, Reznik V. The Culture of Academic Medicine: Faculty Behaviors Impacting the Learning Environment. Acad Psychiatry. 2016.

16. Al-Elq A. Simulation-based medical teaching and learning. J Fam Community Med. 2010.

17. McIntosh C, Macario A, Flanagan B, Gaba DM. Simulation: What does it really cost? Simul Healthc J Soc Simul Healthc. 2006.

18. Zendejas B, Wang AT, Brydges R, Hamstra SJ, Cook DA. Cost: The missing outcome in simulation-based medical education research: A systematic review. Surg (United States). 2013.

19. Walsh K, Jaye P. Simulation-based medical education: Cost measurement must be comprehensive. Surgery (United States). 2013.

20. Hajihosseini F, Zagheri Tafreshi M, Hosseini M, Baghestani AR. Teachers' and postgraduate nursing students' experience of the educational environment in Iran: A qualitative Research. Electron Physician. 2017.

21. Issenberg SB, Scalese RJ. Best evidence on high-fidelity simulation: What clinical teachers need to know. Clinical Teacher. 2007.

22. Cooper DD, Wilson AB, Huffman GN, Humbert AJ. Medical Students' Perception of Residents as Teachers: Comparing Effectiveness of Residents and Faculty During Simulation Debriefings. J Grad Med Educ. 2012.

23. Tofil NM, Peterson DT, Harrington KF, Perrin BT, Hughes T, Zinkan JL, et al. A Novel Iterative-Learner Simulation Model: Fellows as Teachers. J Grad Med Educ. 2014.

24. Ahmed S, Al-Mously N, Al-Senani F, Zafar M, Ahmed M. Medical teachers perception towards simulation-based medical education: A multicenter study in Saudi Arabia. Med Teach. 2016.

25. Morgan PJ, Cleave-Hogg D. Simulation technology in training students, residents and faculty. Current Opinion in Anaesthesiology. 2005. 
26. Tackett S, Bakar HA, Shilkofski NA, Coady N, Rampal K, Wright S. Profiling medical school learning environments in Malaysia: a validation study of the Johns Hopkins Learning Environment Scale. J Educ Eval Health Prof. 2015.

27. Harden RM, Crosby J. AMEE guide no 20: The good teacher is more than a lecturer - The twelve roles of the teacher. Med Teach. 2000

\section{Figures}

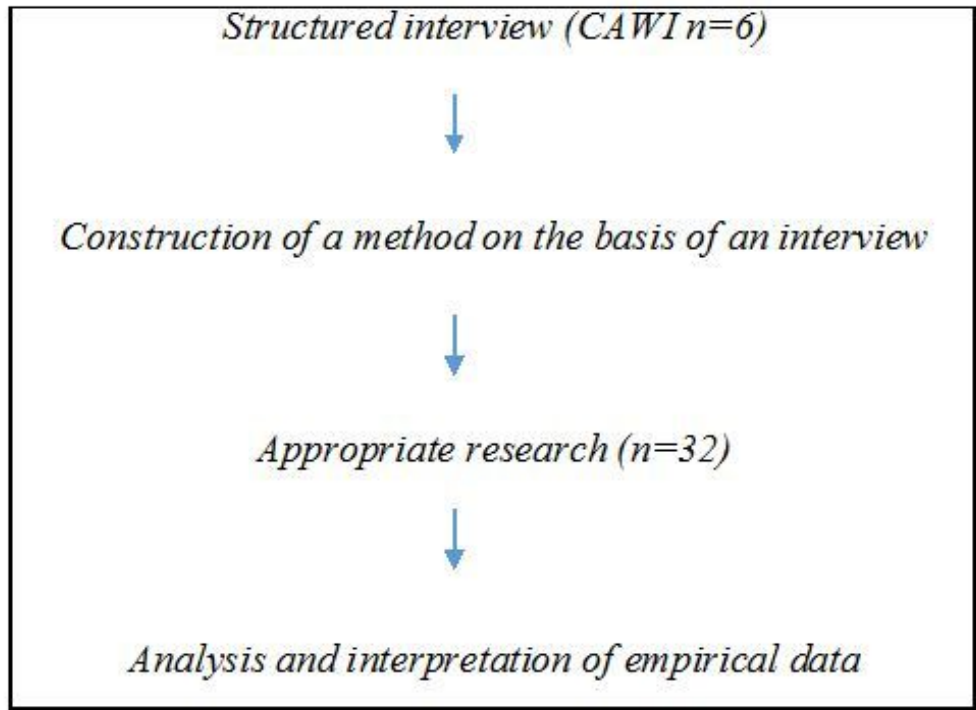

\section{Figure 1}

Construction of WISH - procedure

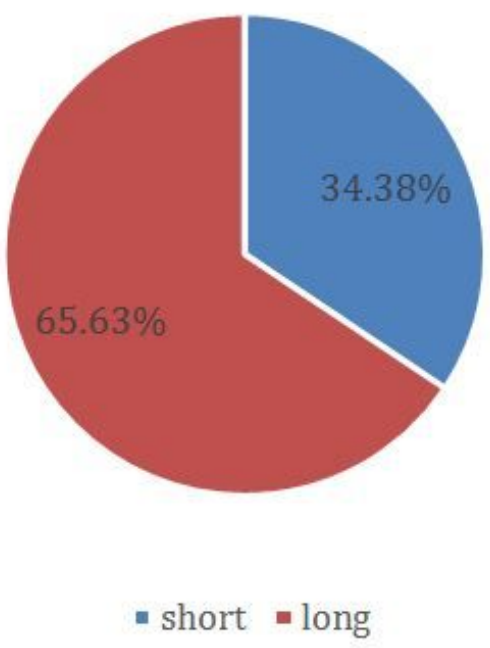

\section{Figure 2}

Number of respondents in terms of years of service

\section{Supplementary Files}

This is a list of supplementary files associated with this preprint. Click to download.

- Torresetal.TheWISHquestionnaireTheappendix.docx 
- Torresetal.TheWISHquestionnaireCOREQ.pdf

Page 14/14 